\title{
The correlation between creatinine serum with total iron binding capacity (TIBC) on patients with sufferers chronic renal disease in Gambiran regional public hospital Kediri city
}

\author{
Nala Fidarotul Ulya ${ }^{1 a^{*}}$, Gilang Kusdinar ${ }^{1 b}$, Kurniawan Santoso ${ }^{1 c}$ \\ ${ }^{1}$ D4 Health Analyst, Faculty of Health Sciences Institut Ilmu Kesehatan Bhakti Wiyata, Kediri, \\ Indonesia \\ analaulya88@gmail.com * \\ * corresponding author
}

\begin{tabular}{l}
\hline ARTICLE INFO \\
\hline Article history: \\
Received date: \\
April 15 1 th, 2019 \\
Revised date: \\
April 24th 2019 \\
Accepted: \\
April 29th 2019 \\
Published: \\
Mei $1^{\text {st }} 2019$ \\
\hline
\end{tabular}

\section{ABSTRACT}

Chronic kidney disease (CKD) is kidney damage that occurs for more than 3 months with a glomerular filtration rate of less than $60 \mathrm{ml} / \mathrm{sec} / 1.73 \mathrm{~m} 2$. WHO estimates that in Indonesia, there will be an increase in PGK in 1995-2025 by $41.4 \%$. Over the past 40 years, Creatinine serum has become the most common and cheap serum marker for kidney function. One of the most common complications in patients with PGK is anemia. Anemia in PGK can be caused by several factors such as EPO deficiency, iron deficiency, etc. One of the usual parameters checking is the iron status of TIBC. This study aims to determine the relationship of serum Creatinine level with TIBC in chronic kidney patients in Gambiran regional public hospital Kediri and sampling taken

Keywords:

CKD

Creatinine Serum

TIBC by quota sampling. The study used cross-sectional using Rank Spearman statistic test. This test is used for abnormally distributed data types. The measured variable was serum Creatinine level with TIBC. The results of this study indicate that the value of $p=(0.000)>\alpha=(0.05)$, so $\mathrm{H} 1$ rejected and $\mathrm{H} 0$ accepted, then there is no relationship between serum Creatinine levels with TIBC in patients with chronic kidney disease in Gambiran Hospital Kediri.

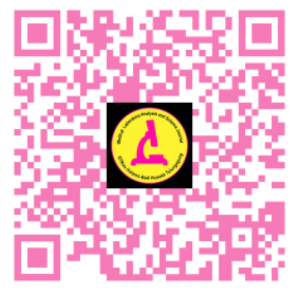

This is an open access article under the CC-BY-SA license

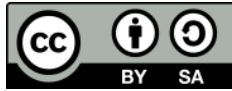

\section{INTRODUCTION}

Chronic kidney disease (CKD) is a pathophysiological process with a variety of etiologies, resulting in a progressive decrease in kidney function, and generally ends with kidney failure. Chronic kidney disease has become a major health problem in the world community. 1

Chronic kidney disease (CKD) is one of the common causes of renal failure. It involves a progressive loss over the course of months in the structure and function of the kidneys, with or without a decreased glomerular filtration rate (GFR). CKD can be diagnosed by its pathological abnormalities, changes in the levels of kidney function markers in the blood or urine, or by imaging investigations. ${ }^{2}$ 
Chronic kidney disease is a significant cause of morbidity and mortality world wide. In India, there is a rising incidence and prevalence of kidney failure, with poor outcomes and high cost. The hallmark of CKD is structural and functional damage of the glomeruli of the kidney. The most important outcomes of this kidney damage are loss of kidney function and cardiovascular disease leading to premature death. ${ }^{3}$

The prevalence of chronic kidney failure in America is around $5 \%-37 \%$ between 1980-2001. ${ }^{4}$ The prevalence of chronic kidney failure in Indonesia is around $0.2 \% .{ }^{5}$ The prevalence of the $\geq 75$ year age group is $0.6 \%$ higher than other age groups. ${ }^{6}$ Based on data from RSUD Gambiran Kediri, the results of preliminary observations of chronic kidney disease patients were approximately 135 per month in 2017.

Chronic kidney disease is kidney damage with a glomerular filtration rate / LFG of less than $60 \mathrm{ml} / \mathrm{min} / 1.73 \mathrm{~m} 2$ characterized by a structural abnormality or impaired renal function irreversible and has lasted for three months or more, with or without a gradual and sustained reduction in glomerular filtration rates. ${ }^{7}$

Rate Glomerular filtration (LFG) is a plasma volume that can be completely cleaned of certain compounds by the kidneys in one unit of time. Serum creatinine is the most well-known endogenous marker used to estimate LFG. Although its use has been recognized since the beginning of the 20th century, serum creatinine has limitations both physiologically and analytically. Physiologically, the two main limitations of using serum creatinine to estimate LFG are variations in creatinine tubular secretion and the dependence of serum creatinine excretion on muscle mass. ${ }^{8}$

$\mathrm{SCr}$ is suggested to be the typical indicator for renal injury assessment, and plays a significant clinical role in the evaluation of GFR in patients with chronic kidney disease. Additionally, about five to ten percent of discharged creatinine comes from distal tubule discharge, which more or less increases in answer to reduced GFR, making it difficult to accurately identify tiny and mild changes in GFR. ${ }^{9}$

According to Astrid's research, with the title "Overview of Serum Creatinine Levels in Kidney Disease patients in Stage 5 non-dialysis Chronic" using a cross-sectional descriptive design, a sample of 35 people was used. Test results obtained for all patients diagnosed with non-dialysis stage 5 chronic kidney disease have increased serum creatinine levels $(100 \%)$ due to renal dysfunction. Creatinine filtration ability will decrease and serum creatinine will increase. ${ }^{1}$

Chronic kidney disease is usually associated with anemia and the level of anemia correlates with the severity of the renal failure. The anemia of renal failure has been attributed to a relative deficiency of erythropoietin, but absolute deficiencies of iron or folate may also play a role. Other contributing factors include heavy- metal toxicity, blood loss, and a reduction in red cell survival induced by toxic radicals. The treatment of the anemia of renal disease has advanced with the development of recombinant human erythropoietin. ${ }^{10}$

Anemia is one of the complications that occur in CKD patients with an incidence rate of $80-90 \%$. If severe kidney damage occurs, the production of erythropoietin in the kidneys is disrupted so that red blood cell production is reduced. Along with kidney damage, bleeding, iron deficiency accompanied by a decrease in glomerular filtration rate, the degree of anemia will increase. ${ }^{11}$

Anemia of renal failure begins relatively early in the development of kidney disease. As the destruction of the kidney progresses, the degree of anemia increases. Although there is a large degree of the patient to patient variability, the Hct generally begins to fall when the plasma creatinine concentration is above $2 \mathrm{mg} / \mathrm{dl}$ and gets lower asglomerular filtration rate (GFR) declines. ${ }^{12}$

Anemia is a leading cause of morbidity in patients with CKD, and it worsens with the stage of the disease. The most common type of anemia is normocytic normochromic anemia due to EPO deficiency and microcytic hypochromic anemia due to iron deficiency. 
Evaluation of $\mathrm{Hb}$ and RBC parameters in patients with CKD helps in classifying the type of anemia and aids in choosing the correct treatment modalities and avoids unnecessary iron overload in the patients. ${ }^{13}$

Anemia prevalence worldwide was estimated at 33\% in 2010 with iron deficiency being the leading cause in half of the cases. In chronic kidney disease (CKD) patients, anemia is a clinically significant burden and it becomes more prevalent with declining glomerular filtration rate (GFR). Anemia is associated with reduced quality of life and increased cardiovascular morbidity and mortality. Erythropoietin (EPO) deficiency remains the major cause of anemia in CKD patients due to the decrease in renal EPO production. ${ }^{14}$

The presence of anemia in patients with mild to moderate reduction in eGFR can be interpreted as of renal origin, however other factors may be contributing, In this cases It is important to identify iron deficiency anemia, which is the most frequent cause of anemia especially in patients receiving antiplatelet or anticoagulant treatments - or of other types of anemia such as deficiency of vitamin B12 or folic acid. Sometimes both types of anemia, renal and iron deficiency may coexist. ${ }^{15}$

Anemia in CKD can also be caused by iron deficiency. Iron deficiency anemia can be diagnosed using conventional iron status laboratory examinations such as serum iron (SI), Total Iron Binding Capacity (TIBC), transferrin saturation, and serum ferritin. ${ }^{16}$

Iron is essential for oxygen binding in red blood cells and is crucial for many other cellular functions. Iron deficiency, even without anemia, has been demonstrated to be an independent risk factor for increased mortality. ${ }^{14}$ Iron deficiency anaemiais also common in patients with chronic kidney disease. Iron deficiency may be absolute, often due to poor dietary intake or sometimes occult bleeding, or functional, when there is an imbalance between the iron requirements of the erythroid marrow and the actual iron supply. ${ }^{17}$

According to previous research, uses descriptive research design, the sample used 92 people and processed using Pearson correlation statistical test and KolmogorovSmirnov categorical test. Evaluating TIBC values, where $80 \%$ of CKD patients experience decreased TIBC levels. ${ }^{18}$

The high prevalence of anemia in patients with Chronic Kidney Disease (GGK) and the number of iron status parameters that can be used to see changes in iron metabolism in these patients requires a specific and sensitive parameter to determine iron status, namely Fe and TIBC parameters (Total Iron Binding Capacity). Both parameters are better than if only checking hemoglobin levels, which are less sensitive to determine iron status, especially in mild anemia in patients with chronic renal failure. ${ }^{16}$

\section{MATERIALS AND METHODS}

This research was conducted at the Laboratory of Gambiran Hospital in Kediri City in July-August 2017. The population of this study was all patients with Chronic Kidney Disease at Gambiran Hospital, Kediri City. The sample used in this study was 32 patients with CKD in Gambiran Hospital, Kediri City. The sampling technique in this study was to use a Non-Random (Non Probability) Quota Sampling. Quota sampling is quotum sampling or quota, done by determining how many samples are needed. Any population member to be taken is not a problem, the important number of quotums that have been determined can be fulfilled. ${ }^{19}$ With a sample size of 32 chronic kidney disease in Gambiran Hospital, Kediri City. The number of samples where the appropriate sample size in the study is between 30 and $500 .{ }^{20}$

In this study using data analysis using a correlation study test. Correlation test is a statistical tool that can be used to compare the measurement results of 2 different variables in order to determine the level of relations between variables. Correlation test used is Pearson test for a parametric test (normal data distribution) which is used to find 
the relationship of two or more variables, but if the distribution of data is not normal it can be used non-parametric statistical test namely spearman test SPSS 16.0 program. ${ }^{21}$

\section{RESULTS AND DISCUSSION}

Table 1: Data on Creatinine and TIBC results in patients with chronic kidney disease in Gambiran Hospital Kediri city

\begin{tabular}{|c|c|c|c|}
\hline \multirow{3}{*}{$\begin{array}{l}\text { Sample } \\
\text { Code }\end{array}$} & \multirow{3}{*}{ age } & \multicolumn{2}{|l|}{ Results } \\
\hline & & Creatinine & TIBC \\
\hline & & $(\mathrm{mg} / \mathrm{dl})$ & $(\mu \mathrm{l} / \mathrm{dl})$ \\
\hline $\mathrm{A} 1$ & 60 & 5,1 & 200,2 \\
\hline $\mathrm{A} 2$ & 57 & 11,95 & 251,5 \\
\hline A3 & 47 & 7,8 & 217,9 \\
\hline A4 & 47 & 5,6 & 318 \\
\hline A5 & 55 & 13,4 & 213,6 \\
\hline$A 6$ & 73 & 16,3 & 233,5 \\
\hline A7 & 71 & 10,1 & 262,6 \\
\hline A8 & 69 & 12,3 & 233,9 \\
\hline A9 & 53 & 9,19 & 258 \\
\hline $\mathrm{A} 10$ & 67 & 10,84 & 268 \\
\hline A11 & 60 & 6,5 & 321 \\
\hline A12 & 75 & 25,3 & 238,3 \\
\hline A13 & 56 & 7,4 & 304 \\
\hline A14 & 71 & 13 & 226 \\
\hline A15 & 66 & 10,9 & 159,9 \\
\hline A16 & 60 & 10,1 & 227,4 \\
\hline A17 & 73 & 13 & 207 \\
\hline A18 & 63 & 8,9 & 298,8 \\
\hline A19 & 58 & 3,3 & 214,3 \\
\hline A20 & 45 & 8,8 & 213,7 \\
\hline$A 21$ & 33 & 2 & 142 \\
\hline A22 & 57 & 8,1 & 277,4 \\
\hline A23 & 68 & 10,8 & 162,5 \\
\hline A24 & 56 & 4,2 & 216,9 \\
\hline A25 & 66 & 13,3 & 195,6 \\
\hline A26 & 69 & 28,3 & 181,3 \\
\hline A27 & 42 & 6,8 & 194 \\
\hline A28 & 73 & 12,8 & 244,3 \\
\hline A29 & 62 & 5,1 & 250,9 \\
\hline A30 & 70 & 11 & 287,4 \\
\hline A31 & 52 & 9,2 & 162 \\
\hline A32 & 68 & 18 & 222,8 \\
\hline
\end{tabular}

In chronic renal failure, there is a steady and continued decrease in renal clearance or glomerular filtration rate (GFR), which leads to the gathering of urea, creatinine and other chemicals in the blood. GFR of less than $60 \mathrm{~mL} / \mathrm{minute} / 1.73 \mathrm{~m} 2$ is the indication of CKD. ${ }^{22} \mathrm{KDIGO}$ additional classified the CKD in different stages which are: GFR 30 to $60 \mathrm{~mL} /$ minute as stage three; GFR 15 to $30 \mathrm{~mL} /$ minute as stage four; and GFR less than $15 \mathrm{~mL} /$ minute as stage five of CKD. In stage five level of serum creatinine is greater than $5.0 \mathrm{mg} / \mathrm{dl}$ in men, and greater than $4.0 \mathrm{mg} / \mathrm{dl}$ in women. ${ }^{23}$ 
Based on the above results it can be seen that the highest number of respondents by age are respondents with ages between $66-75$ years by $44 \%$, ages $56-65$ years by $31 \%$ and ages $46-55$ years by $16 \%$. This is consistent with previous studies that the incidence of CKD reaches its maximum strength in the latter part of life. ${ }^{24}$

It can be seen that 32 CKD patients experienced an increase in serum creatinine $(100 \%)$. This result is not much different from the research conducted at the RSUD dr. Moewardi Surakarta, which shows that there were 31 patients $(93.9 \%)$ who had high creatinine levels. Over the past 40 years, serum creatinine has become the most common and inexpensive serum marker to determine kidney function. Serum creatinine examination is also very helpful in carrying out therapy in patients with kidney function disorders. High and low creatinine levels in the blood are used as important indicators in determining whether a person with impaired renal function needs hemodialysis or not. If renal dysfunction occurs, creatinine filtration ability will decrease and serum creatinine will increase. A doubling of serum creatinine levels indicates a decrease in kidney function by $50 \%$, as well as a threefold increase in serum creatinine reflecting a decline in kidney function by $75 \%$. One of the most important kidney functions is the excretion of metabolic waste products such as creatinine. The function is very disturbed in patients with nondialysis kidney failure as a result of increased serum creatinine levels. Therefore, serum creatinine levels are used as an important indicator to determine kidney function. ${ }^{1}$

The amount of creatinine released by a person every day depends more on muscle mass than muscle mass or protein metabolism, this causes creatinine values in men to be higher because the amount of male muscle mass is greater than the amount of muscle mass of women. Muscle mass and protein metabolism generally cause a constant effect of creatinine formation, except if there is a severe physical injury or degenerative disease that causes damage to muscles. ${ }^{25}$

In this study, it was found that many samples had decreased TIBC values. This is consistent with previous research, that the sample with a TIBC value decreased more than the normal TIBC value. ${ }^{26}$ TIBC which decreases in CKD can be caused by increased ferritin or can occur in anemia of chronic diseases that occur inflammation. However, in regular hemodialysis patients can experience iron deficiency anemia due to blood loss. ${ }^{18}$

In CKD group, iron metabolism is altered compared to controls. Here, serum iron levels are low due to inadequate secretion of erythropoietin, erythropoiesis is halted leading to decreased $\mathrm{Hb}$ and serum iron. Serum ferritin stores are not utilized due to associatedinflammation giving rise to near normal ferritin levels. ${ }^{27}$

From the results of the study entitled the relationship of serum creatinine with TIBC in patients with chronic kidney disease in Gambiran Hospital, Kediri City showed that there was no statistical relationship between serum creatinine and TIBC with $p>0.05$. The results of this study support the theory in the study entitled "Iron chronic disease kidney disease patients" that there was no significant relationship between serum creatinine and TIBC in chronic kidney patients. ${ }^{17}$ This is probably because not all people with chronic kidney disease are caused by iron deficiency anemia. Iron deficiency anemia in patients with CKD is mainly caused by poor nutritional intake, impaired absorption, chronic bleeding, inflammation or infection, and increased iron requirements during correction of anemia with Erythropoietin Stimulating Agent (ESA) therapy. ${ }^{28}$ The other causes than iron deficiency, such as erythropoietin deficiency, uremia related inhibition of erythropoiesis, and short life span of the red blood cell may be responsible for anemia in those subjects. ${ }^{29}$

\section{CONCLUSIONS}

Based on the results of the study, the relationship between serum creatinine levels and TIBC in patients with chronic kidney disease in Gambiran Hospital, Kediri City can be concluded that Statistically, there is no correlation between serum creatinine and TIBC in patients with chronic kidney disease with $p>0.05$. This is because anemia in CKD is 
mainly caused by reduced production of erythropoietin (EPO) and not all sufferers of chronic kidney disease have iron deficiency anemia.

\section{ACKNOWLEDGEMENT}

In the preparation and writing of this thesis cannot be separated from assistance, guidance and support from various parties. Therefore, on this occasion, the author would like to thank all staff and employees of the Gambiran Kediri Hospital Laboratory have helped a lot during the study until completion so that the preparation of this thesis can run smoothly.

\section{REFERENCES}

1. Alfonso, Astrid A, dkk. 2016. Gambaran Kadar Kreatinin Serum pada Pasien Penyakit Ginjal Kronik Stadium 5 non dialisis. Jurnal e-Biomedik, 4 (1).

2. Siddappa JK, Singla S, Al Ameen M, Rakshith SC, Kumar N. Correlation of Ultrasonographic Parameters with Serum Creatinine in Chronic Kidney Disease. J Clin Imaging Sci 2013;3:28.

3. Talib S.H, S. G. kulkarni, V. S. Gulwe, Vajed Mogal. Role of Iron Deficiency Anemia in Patients with Chronic Kidney Disease. DOI: https://doi.org/10.9790/0853-1453102105

4. USRDS Anual Data Report. Chronic Kidney Disease in The United States. 2013

5. Kemenkes RI. (2013). Riset Kesehatan Dasar (RISKESDAS). Jakarta: Badan Penelitian dan Pengembangan Kesehatan.

6. Widyastuti, R. 2014. Korelasi Lama Menjalani Hemodialisis dengan Indeks Massa Tubuh Pasien Gagal Ginjal Kronik di RSUD Arifin Achamad provinsi Riau. Jurnal Gizi Volume 1 No.2 Oktober 2014. Poltekkes Kemenkes Riau: Riau

7. Obrador G T. 2009. Chronic Kidney Failure \&The Uremic Syndrome. In: Lerva EV, Berns J S, Nissension A $R$ (eds) Current Diagnosis \& Treatment Nephrology \& Hypertension. New York. McGraw-Hill. 149.

8. Dewi, yunika. 2014. Performa formula cockcroft-gault, mdrd dan ckd-epi.

9. Xun Liu, Wenbo Zhao, Hongyong Liu. The diagnostic value of serum creatinine and cystatin $\mathrm{c}$ in evaluating glomerular filtration rate in patients with chronic kidney disease: a systematic literature review and meta-analysis.2017,Vol.8(42),pp:7298572999. DOI: https://doi.org/10.18632/oncotarget.20271

10. Kakey, M. and Abdoulrahman, K. /ZJPAS: 2016, 28(6): 57-08

11. Yustisia, Apriani. 2014. Korelasi Antara Penurunan Laju Filtrasi Glomerulus Dengan Beratnya Anemia Pada Penyakit Ginjal Kronik Di RSUD dr. Sayyidimin Magetan. Downloaded from: http: // eprints.ums.ac.id. Accessed January 17 at 10.05 WIB.

12. Bhatta S, Aryal G, Kafle RK. 2011.Anemia in chronic kidney disease patients in predialysis and postdialysis stages, Journal of Pathology of Nepal (2011) Vol. 1, 2629

13. Shastry I, Belurkar S. The spectrum of red blood cell parameters in chronic kidney disease: A study of 300 cases. J Appl Hematol 2019;10:61-6. DOI: https://doi.org/10.4103/joah.joah 1319

14. Aoun M, Karam R, Sleilaty G, Antoun L,Ammar W. 2018.Iron deficiency across chronickidney disease stages: Is there a reverse genderpattern?PLoS ONE 13(1): e0191541. DOI: https://doi.org/10.1371/journal.pone.0191541

15. Aleix Cases, M. Isabel Egocheaga, Salvador Tranche . Anemia of chronic kidney disease: Protocol of study, management and referral to Nephrology. 2018;38:8-12. DOI: https://doi.org/10.1016/..nefroe.2018.01.007

16. Yendriwati. 2008. Status Besi Pada Penderita Gagal Ginjal Kronik dalam menentukan Diagnosa Anemia Defisiensi Besi. Downloaded from: http: //repository.usu.ac.id. Accessed January 17 at 8:45 a.m. WIB 
17. Deori R, Bedanta Bhuyan. Int J Res Med Sci. Iron status in chronic kidney disease patients. 2016 Aug;4(8):3229-3234

18. Ombuh, Cynthia, dkk., 2013. Status besi pada pasien penyakit ginjal kronik yang sedang menjalani hemodialisis di blu rsu. prof. dr. r.d kandou manado. JurnalUniversitas Sam Ratulangi Manado

19. Notoatmodjo, S. 2012. Promosi kesehatan dan Perilaku Kesehatan. Jakarta : Rineka cipta

20. Sugiyono. 2016. Metode Penelitian Kuantitatif, Kualitatif, dan R\&D. Bandung: Alfabeta.

21. Dahlan, M.S. 2014. Statistik Untuk Kedokteran Dan Kesehatan: Deskriptif, Blvariat, Dan Multivariat Dilengkapi Aplikasi Menggunakan SPSS, 6th ed, 1. Jakarta: Epidemiologi Indonesia.

22. Garabed Eknoyan, MD Norbert Lameire, MD, PhD. Kidney Disease: Improving Global Outcomes (KDIGO) CKD Work Group, 2013. KDIGO Clinical Practice Guideline for the Evaluation and Management of Chronic Kidney Disease. Kidney international, Supplement, vol 3, p: 1-150

23. Noor ul Amin, Raja Tahir Mahmood, M. Javaid Asad, Mudassar Zafar, and Asad Mehmood Raja,2014.Evaluating Urea and Creatinine Levels in Chronic Renal Failure Pre and Post Dialysis:A Prospective Study.2014 april;2(2)

24. Vidyasagar Sarpal.2017. Serum Uric Acid Level in Patients with Chronic Kidney Disease: A Prospective Study. Vol 4(11). DOI: https://doi.org/10.17354/ijss/2017/77

25. Ma'shumah, Nuro, dkk. 2014. Hubungan Asupan Protein Dengan Kadar Ureum, Kreatinin, dan Kadar Hemoglobin Darah pada Penderita Gagal Ginjal Kronik Hemodialisa Rawat Jalan Di RS Tugurejo Semarang. Jurnal Gizi Universitas Muhammadiyah Semarang, 3 (1).

26. Ayu P. Nyoman, Suega Ketut, Widiana Gede. Hubungan antara Beberapa Parameter Anemia dan Laju Filtrasi Glomerulus pada Penyakit Ginjal Kronik Pradialisis. J Peny Dalam. 2010;11(3):140-8

27. Veena A. Int J Res Med Sci. Comparison of serum iron, TIBC,transferrin saturation and serumferritin in anemia of chronic renal diseases.2019 Mar;7(3):789

28. Suyatno FE, Rotty LWA, Moeis ES (2016). Gambaran anemia defisiensi pada penyakit ginjal kronik stadium $v$ yang menjalani hemodialisis di Instalasi tindakan hemodialisis rsup prof dr $r d$ kandou manado. Jurnal eclinic, 4(1): 146-151.

29. Sang-Ryol Ryu, Sue K. Park, The Prevalence and Management ofAnemia in Chronic KidneyDisease Patients: Result from the KoreaNCohort Study forOutcomes in Patients With Chronic Kidney Disease(KNOWCKD). J Korean Med Sci 2017; 32: 249256. DOI: https://doi.org/10.3346/jkms.2017.32.2.249 